\title{
MAKNA TUTURAN DALAM PENYELESAIAN PELANGGARAN ADAT MAMBOLOSUAKO MASYARAKAT TOLAKI
}

\author{
La Ino
}

Email: unhalu39@yahoo.co.id, inafkip96@yahoo.co.id

Jurusan Pendidikan Bahasa dan Seni FKIP Unhalu Kendari Sulawesi Tenggara

Alamat Korepondensi: Jalan Perumahan BTN Wirabuana Blok H1/60, RT/RW: 028/010

Kelurahan Anduonohu Kecamatan Poasia Kota Kendari, Sulawesi Tenggara 93232

\begin{abstract}
This article studies about one of cultural products at Tolaki ethnic in South-East Sulawesi Province. The cultural product is mombolusuako. Mombolosuako is a tradition in Tolaki society, in which someone, a man, did a breach of custom that usually happen when the relationship between the girl and the young man is not agreed by the parents and when the girl and the man have different social status. Because it is a breach of custom, there should be a solution according to the custom. In solving this problem (mombolasuako), the custom provides two steps rembinggare and mesokei. The method used in research is descriptive qualitative method. The subject of research is the informants mastering in uttering the solution of the breach of custom (Mombolasuako) in Tolaki society in Lambuya subdistrict. This study is done by using semantic and pragmatic approach. In solving the mombolasuako the people use the language with particular characteristics that is different from their daily language. The language emphasizes beauty especially in its use of language speech and metaphors. The rembinggare is meaningful for the man family, as to show his intention to solve the problem, and it is meaningful for the family of the girl as the solution of the problem so that they will be avoided from shame. In the process of mesokei there is a negotiation and settlement among two families to get the best solution for both of them.
\end{abstract}

\section{Keywords}

Adat, Tolaki, Mombolosuako, Rembinggare

\section{Pendahuluan}

Membahas tentang kebudayaan khususnya bidang kebahasaan, keduanya tidak boleh terpisahkan. Hal ini karena kesusastraan memiliki hubungan yang erat dengan kebudayaan yaitu sastra menggunakan bahasa sebagai medianya, sedangkan bahasa itu sendiri merupakan bagian dari kebudayaan dan sastra merupakan bagian dari kesenian, sementara kesenian juga merupakan cabang dari kebudayaan.

Sistem adat istiadat mengandung muatan sastra yang sangat erat dengan makna tuturan yang digunakan dengan nilai-nilai etika dan estetika yang cukup berharga bagi masyarakatnya. Adat istiadat Tolaki berasaskan kalo sara sebagai simbol persatuan masyarakat Tolaki.

Salah satu adat istiadat di dalam masyarakat Tolaki, yaitu acara penyelesaian pelanggaran adat mombolasuako. Pelaksanaan penyelesaian adat mombolasuako tersebut biasanya menggunakan bahasa yang mempunyai ciri-ciri tertentu yang berlainan dengan penggunaan bahasa sehari-hari. Acara pelanggaran adat mombolasuako merupakan bentuk adat istiadat masyarakat Tolaki yang pelaksanaannya dilakukan keluarga laki-laki yang datang secara resmi kerumah pihak keluarga perempuan. Hal ini dimaksudkan untuk memohon maaf dan pernyataan kesediaan pihak laki-laki untuk memenuhi segala ketentuan yang berlaku dalam adat, menyangkut pelanggaran adat membolasuako. Mombolasuako merupakan bentuk pelanggaran adat dengan cara melarikan anak gadis orang. Hal tersebut dianggap sebagai pelanggaran adat karena dianggap pihak laki-laki tidak menghormati adat yang ada yaitu melakukan pernikahan sesuai dengan prosedur yang berlaku di masyarakat. Bahasa yang digunakan dalam acara ini sangat menonjolkan pemakaian bahasa yang indah, terutama kelihatan pada gaya bahasanya, dan pemakaian bahasa-bahasa kiasan di dalamnya. 


\section{Penutup}

Mombolosuako merupakan bentuk pelanggaran adat yang biasa dilakukan apabila hubungan antara si gadis dengan si pemuda tidak disetujui oleh orang tua dan status sosial antara seorang gadis dan seorang pemuda berbeda. Pelaksanaannya terdiri atas dua tahapan yaitu tahapan rembinggare, dan tahapan mesokei.

Makna yang terkandung dalam rembinggare khususnya pembicara pihak laki-laki yaitu sebagai wujud kewajiban pihak pembicara untuk menyelesaikan masalah yang ada, agar keluarga si gadis tidak dilanda kebingungan dan tidak lama menanggung beban psikologis sebagai komunitas sosial yang mempunyai rasa malu. Di samping itu, mengingatkan keluarga perempuan agar jangan berbuat yang tidak diinginkan terhadap anak lakilaki yang telah membawa lari anak gadis orang sebelum mencari jalan terbaik atau penyelesaiannya melalui pertemuan adat.

Makna yang terkandung dari jawaban pihak pembicara perempuan dalam acara rembinggare yaitu perwujudan tanggung jawab pembicara (pabitara) pihak perempuan untuk menanggapi secara positif kedatangan keluarga pihak laki-laki untuk mencari kesepakatan tentang permasalahan yang ada. Di samping itu, kesungguhan pembicara pihak perempuan untuk mencari jalan yang terbaik atas pelanggaran adat yang dilakukan oleh keluarga pihak laki-laki.

Makna yang terkandung dalam acara mesokei khususnya pembicara pihak laki-laki yaitu: pembicara mengharapkan diterima keinginannya untuk melaksanakan kegiatan penyelesaian adat. Pembicara mengharapkan agar orang tua si gadis mau memaafkan dan menerima upaya untuk menetralisir serta mencari solusi terbaik terhadap tindakan dari pihak laki-laki. Penutur mengharapkan agar segenap famili dan pendengar dapat menyaksikan dengan seksama acara tersebut, agar terjaganya stabilitas pertemuan adat.

Makna yang terkandung dari jawaban tolea pihak perempuan dalam tahapan mesokei yaitu: pembicara pihak perempuan (si gadis) mengharapkan agar juru bicara pihak laki-laki puas karena apa yang diinginkan oleh pihak laki-laki telah diterima dengan baik oleh pihak keluarga perempuan. 


\section{DAFTAR PUSTAKA}

Araby, Ahmad dkk. 1983. Sastra Lisan. Jakarta: Depdikbud.

Atmazaki. 1986. Ilmu Sastra (Teori dan terapan). Bandung: Angkasa Prima.

Badudu, J. S. 1972. Kamus ungkapan. Bandung: Angkasa Prima

Danadjaya, James. 1994. Folklor Indonesia: Ilmu Gossip, Dongeng, Dan lain-lain. Jakarta: Grafiti Press.

Depdiknas. 1984. Ungkapan Tradisional sebagai Sumber Informasi Kebudayaan Sumatra utara. Jakarta: Dirjen Kebudayaan.

1984. Ungkapan Tradisional sebagai Sumber Informasi Kebudayaan Kalimantan Selatan. Jakarta: Dirjen Kebudayaan.

Gaffar, Zainal Abidin dkk. 1990. Struktur sastra lisan Musi. Jakarta: Depdikbud. 1991. Struktur sastra lisan Serawi. Jakarta: Depdikbud.

Hasan, Fuad. 1986. Renungan Budaya. Jakarta: Balai pustaka.

Hutomo, Suripan Sadi. 1983. Panduan Penelitian Satra lisan Daerah. Jakarta: Depdikbud.

Ihroni, T.O (ed). 1986. Pokok-Pokok Antropologi Budaya. Jakarta: Gramedia.

Koentjaraningrat. 1984. Kebudayaan Mentalitas Dan Pembangunan. Jakarta: Gramedia Pustaka.

Moeliono, Anton (ed).1989. Kamus Besar Bahasa Indonesia. Jakarta: Depdikbud.

Poerwadarminta, W.J.S. 1984. Kamus Umum Bahasa Indonesia . Jakarta: Balai Pustaka.

Sikki, Muhamad. Tanpa tahun. Nilai Budaya dalam Susastra Sulawesi Selatan. Jakarta: Pusat Pembinaan Bahasa.

Simanjuntak, B.S. 1984. Kesusastraan Indonesia I dan II. Jakarta: Gramedia.

Tarimana, Abdurrauf. 1993. Kebudayaan Tolaki. Jakarta: Balai Pustaka. 